\title{
SUMMARY JURISDICTION IN BANKRUPTCY: AN EXPANDING CONCEPT
}

\begin{abstract}
A
primary purpose of the Bankruptcy Act ${ }^{1}$ is the expeditious settlement of a debtor's estate for the benefit of his creditors. ${ }^{2}$ Consequently, Congress has permitted the bankruptcy courts to dispense with many of the formalities of a plenary suit, and to proceed summarily, through a referee, in administering a bankrupt's estate. ${ }^{3}$ The tradition of formal trial is such, however, that Congress has preserved that right to a person asserting a bona fide adverse claim ${ }^{4}$ to property not in the actual or constructive possession of the trustee. ${ }^{5}$ Therefore, any interest in such
\end{abstract}

152 STAT. (I938), II U.S.C. \$§ I-I 255 (1952).

2 President Hoover in his message to Congress in 1932 said, "A sound bankruptcy system should operate First, to relieve honest but unfortunate debtors of an overwhelming burden of debt; Second, to effect a prompt and economical liquidation of insolvent estates; and Third, to discourage fraud and needless waste of assets by withholding relief from debtors in proper cases. ..." S. Doc. No. 65, 72d Cong., Ist Sess. 6 (1932). These aims were incorporated into the Chandler Act of 1938,52 STAT. 883, Ix U.S.C. §§ I-I255 (1952). See H.R. REP. No. 1409, 74th Cong., 2d Sess. 3 (I936); S. REP. No. 1916, 74th Cong., 2d Sess. 3, 4 (1936).

3 Though the act itself, except in a few instances, [Bankruptcy Act, $\$ 6_{7}(\mathrm{a})$, $67(f), 70(a) ; 52$ STAT. $875(a)(f), 879$ (1938), II U.S.C. $\$ \$$ ro7(a), ro7(f), I 1 (a) (8) (1952)] does not specify when summary proceedings are permissible, the necessary exercise of the bankruptcy courts' equitable powers [Young v. Higsbee, 324 U.S. 204, 214 (1945); Pepper v. Litton, 308 U.S. 95 (1939)] enables them to proceed summarily in administering the bankruptcy estates. Bankruptcy Act $\S 2,52$ STAT. 842 (1938), I1 U.S.C. § I I (1952); I Collier, Bankruptcy i 2.09 (I4th ed. I 948); 2 id. $\$ 23.04$.

A bona fide adverse claim must be substantial and not merely colorable. Harrison v. Chamberlin, $27 x$ U.S. IgI (x926).

"Section $23(a)$ of the Bankruptcy Act provides: "The United States district courts shall have jurisdiction of all controversies at law and in equity, as distinguished from proceedings under this Act, between receivers and trustees as such and adverse claimants, concerning the property acquired or claimed by the receivers or trustees, in the same manner and to the same extent as though such proceedings had not been instituted and such controversies had been between the bankrupts and adverse claimants." 52 STAT. 854 (1938), II U.S.C. $\S 46(a)$ (1952). This section, therefore, requires that all proceedings which are not "proceedings under this Act" must be maintained in plenary proceedings in a court where the bankrupt could have sued the adverse claimant. See City of Long Beach v. Metcalf, I03 F.2d ${ }_{4} 8_{3}$ (9th Cir. 1939), cert. denied 308 U.S. 602 (1939), and cases there cited. Section 23, supra, has been construed to be merely a limitation on the jurisdiction of the bankruptcy courts, not a grant of separate plenary jurisdiction. Williams v. Austrian, 33 I U.S. 642 (I947). See generally, Mussman and Riesenfeld, Jurisdiction in Bankruptcy, 13 LAW \& ConTEMP. ProB. 88 (1948). 
property asserted affirmatively ${ }^{6}$ by a trustee in bankruptcy, would ordinarily have to be pursued in a formal plenary suit, thereby impeding, to a certain extent, the administration of the estate. ${ }^{7}$

Under the act, however, it is possible for an adverse claimant to consent to summary jurisdiction ${ }^{8}$ either expressly ${ }^{0}$ or by implication. ${ }^{10}$

- Of course, the trustee may defensively use any claims he may have against the adverse claimant as set-offs, [Bankruptcy Act, $\$ 68,52$ STAT. 878 (1938), I I U.S.C. $\$$ Io8 (1952); 4 ColliER, op. cit. supra note $3,068.20$ ] for the obvious reason that a set-off requires no separate grounds of jurisdiction to support it. 3 MOORE, FEDERAL PRACTICE if 13.19 ( 2 d ed. 1948).

TSee Harrison v. Chamberlin, 27 I U.S. I9I (I926); Gailbraith v. Vallely, 256 U.S. 46 (192I) ; Louisville Trust Co. v. Commigor, 184 U.S. 18 (1902); Mueller v. Nuegent, 184 U.S. I (1902).

${ }^{8}$ This consent operates as a waiver of the right to a plenary suit. Since it is well settled that a jurisdictional defect cannot be waived [McNutt v. General Motors Acceptance Corp., 298 U.S. 178 (1936) ], it is apparent that the right to a plenary suit does not relate to the jurisdiction of the court, but rather to the venue of the action. R.F.C. v. Riverview State Bank, 217 F.2d 455 (roth Cir. 1954).

${ }^{\circ}$ Section ${ }_{23}$ (b) of the Bankruptcy Act provides: "Suits by the receiver and the trustee shall be brought or prosecuted only in the courts where the bankrupt might have brought or prosecuted them if proceedings under this Act had not been instituted, unless by the consent of the defendant except as provided in sections 60,67 , and 70 of the Act." $\$ 2$ STAT. 854 (1938), I I U.S.C. $\$ 46$ (b) (1952) [emphasis supplied]. It has been held that a person may consent under this section to summary proceedings as well as to a specific forum. Harris v. Avery Brundage Co., 305 U.S. 160, 164 (1938); MacDonald v. Plymouth Trust Co., 286 U.S. 263 (1932); Page v. Arkansas Natural Gas Corp., 286 U.S. 269 (1932). Sections 60 and 70 [52 STAT. 869, 879 (1938), II U.S.C. $\S \S 96$, I 10 (1952)], referred to as exceptions by section $23(\mathrm{~b})$, stipra, relate to the power of the trustee to avoid fraudulent and preferential transfers, and provide that the bankruptcy courts shall have concurrent jurisdiction with state courts in these matters. Such jurisdiction, however, extends only to the subject matter, and does not include the power to proceed summarily, absent the defendant's consent. SA REMINGTON, BANKRUPTCY $\$ 2350$ (5th ed. 1953). Section 67 [52 STAT. 875 (1938), 11 U.S.C. $\$ 107$ (1952)], also referred to as an exception under section 23 (b), supra, relates to liens upon the property of the bankrupt and gives the bankruptcy court exclusive and summary power to decide all matters in connection with those liens.

${ }_{10}$ Where the adverse claimant's actions are inconsistent with his right to a plenary suit, he is deemed to have waived that right and impliedly consented to summary jurisdiction. Columbia Foundry Co. v. Lochner, I79 F.2d 630 (4th Cir. 1950); Moonblatt v. Kosmin, 139 F.2d 412 (3d Cir. 1943). Sce 2 Collier, op. cit. supra note 3 , $\$ 23.08$, for the form of actions deemed to be implied consent. In 1943 the Supreme Court in its decision of Cline v. Kaplan, 323 U.S. 97 (1944), held that an adverse claimant, who entered bankruptcy proceedings to defend against a turnover order, could object to the summary jurisdiction of the bankruptcy court at any time before the final order. The decision was criticized for not giving full effect to the waiver provisions of Rule $\mathrm{r}_{2}(\mathrm{~h})$ of the Federal Rules of Civil Procedure as applied by General Orders 37 of the General Orders in Bankruptcy (1939). Sec 2 Collier, op. cit. supra note 3, T 23.08. Congress subsequently amended the act to overrule this decision by providing that a person who entered bankruptcy proceedings, and did not object to the summary 
And since a very common basis of consent by implication is the filing of a proof of claim, ${ }^{11}$ it has become significant to determine the extent to which jurisdiction so conferred makes available to the trustee a means of obtaining affirmative relief summarily.

The doctrine that summary jurisdiction to grant affirmative relief is conferred by the filing of a proof of claim had its inception in 1935 in the United States Supreme Court case of Alexander v. Hillman.12 The Court there ruled that creditors entering an equity receivership by filing claims impliedly subjected themselves to the court's jurisdiction for the purpose of rendering a judgment against them on a counterclaim asserted by the receiver. ${ }^{13}$ While this case did not involve bankruptcy proceedings, the analogy was evident, and the courts were not slow in its application. In 1938 , a court of appeals decision ${ }^{14}$ relied on the rationale of the Hillman case and held that a creditor, filing a proof of claim against a bankrupt's estate for monies owing him under a contract with the bankrupt, was subject in summary proceedings to a counterclaim for affirmative relief arising out of that contract. ${ }^{15}$ This rule was not long in gaining favor, and today it represents the modern trend in this

jurisdiction of the court, by answer or motion filed before the expiration of the time fixed by law, or set by the court, would be deemed to have consented to summary jurisdiction. Bankruptcy Act, $\S_{22}(7), 52$ STAT. 842 (1938), Ix U.S.C. $\S_{11}(\mathrm{a})(7)$ (1952). See H.R. Rep. No. 2320, 82d Cong,, 2d Sess. 4 (1952). This amendment was held to apply only to the person entering banhruptcy proceedings through preemptory process, e.g. a turnover order, and therefore would not apply in cases where the claimant came in voluntarily by filing a proof of claim. In re Houston Seed Co., I22 F. Supp. 340 (N.D. Ala. 1954).

${ }^{11}$ See note 16 infra.

12296 U.S. 222 (x935).

${ }^{13}$ In the Hillman case receivers were appointed to collect the assets of a defunct corporation. Individuals who, as directors and officers, had dominated the corporation filed the claims. The receivers filed an ancillary bill, asserting counterclaims against these individnals for funds of the corporation fraudulently diverted to their personal use. The Court declared that the claimant's right to a plenary suit was a procedural right and could be waived by filing a proof of claim. The Court then went on to say that a court of equity having jurisdiction of all the parties brought before them could decide all matters in dispute and decree complete relief. 296. U.S. at 241, 242.

${ }^{16}$ Florance v. Kresge, 93 F.2d 784 (4th Cir. 1938).

${ }^{10}$ The court in the Kresge case, $i d$. at 786 , said: "We see no reason why the court of banhruptcy should not pass upon the claims in favor of the bankrupt estate and set them off against the claims filed against the estate and its receivers; and, under the recent decision of the Supreme Court in Alexander v. Hillman, .... we see no reason why the court, which is a court of equity even though exercising special statutory powers, should not proceed to render judgment against Kresge for any balance found to be due by him." This was the same court whose decision was reversed by the Supreme Court in the Hillwan case. Alexander v. Hillman, 75 F.2d 45 I (4th Cir. 1935). 
area. ${ }^{16}$ However, in deference to the procedural rights of adverse claimants, the courts have heretofore restricted the grant of affirmative relief, where there has been a "consent" to the jurisdiction by the filing of a claim, to matters arising out of the same transaction as the proof of claim. ${ }^{17}$

But in the recent case of Interstate National Bank of Kansas City v. Luther, ${ }^{18}$ the Court of Appeals for the Tenth Circuit has rejected even this limitation. There, the referee was allowed the summary power to grant affirmative relief in avoiding a preference ${ }^{19}$ made to a creditor

${ }^{16}$ In re Solar Mfg. Corp., 200 F.2d 327 (3d Cir. 1952), cert. denied 345 U.S. 940 (1952); In re Nathan, 98 F. Supp. 686 (S.D. Cal. 1951); In re Petroleum Conversion Corp., 99 F. Supp. S99 (D. Del. 195I), aff'd per curiam 196 F.2d 728 (3d Cir. 1952); Columbia Foundry Co. v. Lochner, 179 F.2d 630 (4th Cir. 1950); In re Mercury Engineering Co., 60 F. Supp. 786 (S.D. Cal. 1945); Chase Nat'l. Bank of New York v. Lyford, 147 F.2d 273 (2d Cir. 1945); In re Gillespie Tire Co., 54 F. Supp. 336 (W.D.S.C. 1 942). See also Nadler, Summary Jurisdiction to Render A firmotive Judgment on Counterclaims, Set-offs, and Reclamations, 29 REF. J. 39 (1955). In Columbia Foundry Co. v. Lochner, supra, the court stated that, in their opinion, Section 23 of the Bankruptcy Act, 52 STAT. 854 (1938), I I U.S.C. $\$_{46(a)}$ (1952), applied only to situations where the trustee instituted a suit against the adverse claimant. Therefore, since section 23, supra, did not apply to a situation where an adverse claimant entered bankruptcy proceedings voluntarily, neither an express nor an implied consent was required to determine his rights in adversely held property. This theory, though it appears to be tenable, has not gained a following. See 25 N.Y.U.L.Q. REV. 893 (1950). The court also relied on the Hillman case.

${ }_{17}$ Columbia Foundry Co. v. Lochner, 179 F.2d 630 (4th Cir. 1950). See the cases cited in the dissenting opinion in Interstate National Bank v. Luther, 221 F.2d 382, 400 (roth Cir. 1955). See note 19 infra.

${ }^{18} 221$ F.2d 382 (10th Cir. 1955), cert. granted, 24 U.S.L. WEEK 3081 (U.S. Oct. II, 1955) (No. 242). This was a 3-2 decision.

${ }^{19}$ A preference is a transfer for an antecedent debt, made within four months of the institution of bankruptcy proceedings, while insolvent, to a creditor who has reasonable cause to believe that the debtor is insolvent, so as to enable that creditor to obtain a greater percentage of his debt than other creditors of the same class. Bankruptcy Act, $\S 60,52$ STAT. 869 (1938), in U.S.C. $\$ 96$ (1952). The referee is allowed to determine whether or not there is a preference, and to disallow and hold the claim of the creditor in abeyance unless the preference is paid in toto to the court. Bankruptcy Act $\S 57(\mathrm{~g}), 52$ STAT. 866 (1938), I I U.S.C. $\S 93(\mathrm{~g})$ (1952). Therefore a preference is a proper defense which a trustee might interpose to disallow a claim, but there has been much dissension among the courts as to whether it is the proper subject matter for a counterclaim. See In re Solar Mfg. Co., 200 F.2d 327 (3d Cir. 1952), cert. denied 345 U.S. 940 (1952); In re Nathan, 98 F. Supp. 686 (S.D. Cal. 1951) (allowing affirmative relief in summary proceedings on a counterclaim for a preference arising out of the same transaction as the subject matter of the proof of claim). The latter case was approved in 37 IowA L. REv. 431 (1952), and criticized in 27 N.Y.U.L.Q. REv. 142, 146 (1952). But see Kleid v. Ruthbell Coal Co., 131 F.2d 372 (2d Cir. 1942), where, on facts similar to the above two cases, the court held that a 
filing a claim in the bankruptcy proceedings, notwithstanding the fact that the preference arose out of a transaction unrelated to the proof of claim..$^{20}$

Obviously, the desirability of such an extension should not be debated solely in terms of whether the claimant "consented" to the court's summary power to grant affirmative relief against it. Admittedly, under the act, jurisdiction can be conferred by consent; and surely the filing of a proof of claim is conduct which can logically be said to constitute an "implied consent." But in the end, the scope of the bankruptcy court's summary jurisdiction should not be determined by legal terminology, but rather in terms of the conflict between the primary purpose of the Bankruptcy Act and the tradition of a formal trial. In this context, the rule of the Luther case has in its favor the fact that it expedites the settlement of debtors' estates. ${ }^{21}$ The countervailing argument is that its application will too severely prejudice the procedural rights of the adverse claimant.22

As to the possibility of such prejudice, it should be observed that the basic elements of a fair trial, with the exception of the right to a jury, are preserved in summary proceedings. ${ }^{23}$ While it is true that the presiding offcer is a referee rather than a judge, ${ }^{24}$ it is becoming increasingly

preference could not be asserted as a counterclaim for affirmative relief. The courts in the Natian case, supra, and the Solar case, supra, relied on the fact that, since this preference arose out of the same transaction or occurrence as the proof of claim, it was a compulsory counterclaim under Rule I $_{3}(\mathrm{a})$ of the Federal Rules of Civil Procedure, and therefore the adverse claimant could not withdraw his claim, since the counterclaim could not remain pending for independent adjudication under Rule $4_{11}$ (a) (2) of the Federal Rules of Civil Procedure.

${ }^{20}$ The court, after deciding that the adverse claimant had impliedly consented to summary jurisdiction, stated that since the Federal Rules of Civil Procedure apply to bankruptcy by virtue of General Order 37 , there was no reason to confine a trustee's right to assert counterclaims to the same transaction or occurrence as the proof of claim, especially in the face of the fact that Rule I $_{3}$ (b) (permissive counterclaim) expressly allows otherwise. The court relied heavily upon the argument that, since the referee had to determine the preference, that determination would be res judicata in a plenary suit.

${ }^{21}$ Otherwise, the trustee would only be allowed to use so much of his counterclaim defensively as would be necessary to extinguish the claim. Thereafter he would have to proceed in a plenary suit for affirmative relief.

22 See text to note 5 supra.

${ }^{23}$ While it is true that summary proceedings are less formal than plenary proceedings, the requisites of due process, i.e. due notice and hearing, are maintained. See Central Republic Bank \& Trust Co. v. Caldwell, 58 F.2d 72 I (8th Cir. 1932), for a complete description. Also see 2 Collier, op. cit. sapra note $3,023.02$.

24 Bankruptcy Act, $\S$ I (9), 52 STAT. 840 (1938), I I U.S.C. § I (9) (I952). 
evident that, as to their respective competence, the distinction between the two is in name only. ${ }^{25}$ In any event, the findings and decisions of the referee are reviewable by the district court. ${ }^{26}$

Also significant is the fact that filing a proof of claim unquestionably empowers the referee to set-off any claims of the trustee, even if unrelated to the subject matter of the creditor's claim. ${ }^{27}$ If the alleged possibility of prejudice in any way concerns the referee's competence, his power to decide an unrelated claim asserted defensively by the trustee should certainly be persuasive as to his ability to grant relief affirmatively on the same claim. ${ }^{28}$ In addition, there is only a remote possibility that various noncommercial claims, not ordinarily adjudicated by a referee, may be asserted affirmatively, since the Bankruptcy Act gives the trustee title to the more personal rights of action of the debtor only if they are subject to attachment under local law. ${ }^{20}$

It should be evident, then, that application of the rule of the Luther case is not likely to sacrifice the procedural rights of adverse claimants, exchanging them for a speedier disposition of the debtor's estate. Rather, the decision seems to effect a very desirable expansion of the bankruptcy courts' summary jurisdiction.

David Tallant, Jr.

${ }^{25}$ Referees are required to be members of the bar, Bankruptcy Act, $\S 35,52$ STAT.

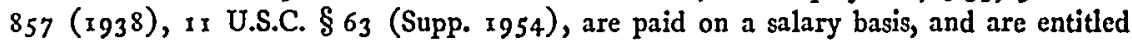
to retirement benefits, section 40, 52 STAT. 859 (1938), II U.S.C. $\$ 68$ (1952), are removable (if full time referees) only for cause, and serve for a 6 year term, section 34, 52 STAT. 857 (1938), I I U.S.C. \$ 62 (1952). Gendel, Jurisdiction of a Referee in Bankruptcy to Render Affirmative Judgment on a Counterclaim in Favor of a Trustee, 26 So. Calif. L. Rev. 167,170 (1952).

${ }^{20}$ Bankruptcy Act, $\$ 39$ (c), 52 STAT. 858 (1938), x U.S.C. $\$ 67$ (c) (I952).

${ }^{27}$ See note 6 supra.

${ }^{28}$ The facts that a referee must necessarily determine in framing his order are res judicata between the parties in a subsequent suit. Griffin v. Vought, 175 F.2d 187 (2d Cir. I949); Metz v. Knobel, 2 I F.2d 317 (2d Cir. I927).

${ }^{20}$ Section 70(a) of the Banhruptcy Act provides that: "[R]ights of action ex delicto for libel, slander, injuries to the person of the bankrupt or of a relative, whether or not resulting in death, seduction, and criminal conversation shall not vest in the trustee unless by the law of the State such rights of action are snbject to attachment, execution, garnishment, sequestration, or other judicial process. ..." 52 STAT. 879 (1938), I I U.S.C. $\S$ I I0(5) (1952). See 4 Collier, op. cit. supra note $7,770.28$ at 1163 . 